\title{
Production of Quorum Sensing Inhibitors in Growing Onion Bulbs Infected with Pseudomonas aeruginosa E (HQ324110)
}

\author{
Mohamed H. Abd-Alla and Shymaa R. Bashandy \\ Botany Department, Faculty of Science, Assiut University, Assuit 71516, Egypt \\ Correspondence should be addressed to Mohamed H. Abd-Alla, mhabdalla2002@yahoo.com \\ and Shymaa R. Bashandy, shymaa_ryhan@yahoo.com
}

Received 30 August 2011; Accepted 3 October 2011

Academic Editors: D. Liu and D. A. Saffarini

Copyright ( $) 2012$ M. H. Abd-Alla and S. R. Bashandy. This is an open access article distributed under the Creative Commons Attribution License, which permits unrestricted use, distribution, and reproduction in any medium, provided the original work is properly cited.

\begin{abstract}
Eighteen organic compounds were present in growing onion bulbs cultivar Giza 6 infected with P. aeruginosa, but only fourteen of them are present in dry infected onion bulbs; however, four compounds were missing in dry onion. The missing compounds in dry infected onion bulbs are pantolactone, 4,5-dihydro-4,5-dimethylfuran-2(3H)-one, myristic acid, and linoleic acid. All of them were detected in growing onion (living cell) during Pseudomonas aeruginosa infection, and it is hypothesized that it may be produced by plants and act as defence system. Pantolactone and myristic acid were selected to explore their effects on growth and virulence factors of Pseudomonas aeruginosa. Exogenous application of pantolactone and myristic acid significantly inhibited pyocyanin production, protease, and lipase and polygalacturonase activity but did not have any significant effects on bacterial growth. The inhibition of virulence factors without reduction in bacterial growth may be providing strong support that these chemical molecules are general quorum sensing inhibitors than an antibacterial effect. Disruption of quorum sensing of pathogen indicates that this new approach has potential in fighting bacterial infections in human and plants.
\end{abstract}

\section{Introduction}

Pseudomonas aeruginosa is an opportunistic pathogen capable of eliciting soft-rot symptoms when infiltrated into a variety of plants including tomato, lettuce, onion, and tobacco [1-5]. P. aeruginosa is also known to be a common colonizer of many fruits and green plants and can persist without causing disease symptoms [6]. Virulence of $P$. aeruginosa is multifactorial, involving both secreted and cell-associated bacterial products, such as proteases, lipase, polygalacturonase, and pyocyanin [7]. Expression of these virulence factors appears to be controlled by signal moleculedependent cell-cell communication systems, which are used by $P$. aeruginosa to monitor its own population density in a process known as quorum-sensing and global virulence regulation networks [8].

Plants have evolved multiple defense strategies for combating invading pathogens. Plant defence, including physical defence based on, for example, cuticle structure, various thorns and hairs, and chemical defence based on synthesis of chemical compounds can be divided into constitutive and inducible defence components $[9,10]$. Constitutive defence can be found in healthy plants that are not harmed by biotic or abiotic stressors. In many circumstances, constitutive defence is not enough to protect against pathogen $[11,12]$.

Microbial infection will lead to form or increase some new protective plant structures or production of new chemical compounds in plant tissues. Tissue concentration and volatile emissions of organic compounds may both be elevated, but responsiveness of different compounds depends on the type of attacking organism [12].

Many eukaryotic organisms are able to produce and secrete compounds that mimic the quorum sensing signals of bacteria and thus affect the behavior of associated bacteria $[13,14]$. The halogenated furanones of Delisea pulchra, a marine red alga, were observed to share structural similarity with bacterial acyl homoserine lactone and were shown to strongly and specifically inhibit quorum-sensing-regulated behaviors in a variety of bacterial species [15]. Higher plants, such as pea, crown vetch, M. truncatula, rice, soybean, and 
tomato, were also shown to produce substances that appear to mimic the activities of acyl homoserine lactone and have specific effects on quorum-sensing-regulated behaviors in bacteria [15-17].

The present work aimed to identify some chemical molecules induced in growing onion infected with P. aeruginosa. Also, the effect of exogenous application of pantolactone and myristic acid on the growth and production of virulence factors of $P$. aeruginosa in vitro has been addressed. Chemical molecules that target quorum sensing have been proposed as an antivirulence strategy that could be used in control of bacterial disease.

\section{Material and Method}

2.1. Bacterial Strains. Pseudomonas aeruginosa isolate E (HQ324110) was recovered from onion bulbs (Allium cepa) collected from vegetable markets of Assuit governorate, Egypt, and was used in this study. Pseudomonas aeruginosa isolate $\mathrm{E}$ was identified based on phenotypic characteristics and by sequencing of the $16 \mathrm{~S}$ rRNA gene [4].

\subsection{Determination of Some Chemical Compounds in Infected} and Uninfected Onion Bulbs. Pseudomonas aeruginosa E (HQ324110) was inoculated into growing (cultivated) onion bulbs cv Giza 6 and dry bulb storage onions cv Giza 6. With the use of a $0.25 \mathrm{G}$ syringe needle, wounds were made on an onion bulb to inoculate the causal agent. The bacterial inocula were obtained from 2-day-old cultures on $\mathrm{KB}$ broth medium incubated at $30^{\circ} \mathrm{C}$. The bacterial causal agent was inoculated longitudinally from the neck part and transversely from the outer to the inner part of the onion bulb at the level of $5 \mathrm{~mL}$ of Pseudomonas aeruginosa $\left(10^{8}\right.$ cell $\left.\mathrm{mL}\right)$ on wound. Inoculated onion bulbs were incubated at $30^{\circ} \mathrm{C}$ in a moist chamber. Inoculated bulbs were examined daily for development of symptoms. Uninfected growing and dry onion bulbs were used as control. Three days after infection, $1 \mathrm{~g}$ of plant tissue was grounded in 2 equal volumes of ethyl acetate containing $0.01 \%$ (final concentration) glacial acetic acid using mortar. The ethyl acetate phase was collected and stored at $20^{\circ} \mathrm{C}$. Samples of extracts were dried under a stream of sterile air, and each residue was redissolved in $50 \%$ methanol and analyzed by Gas chromatographymass spectrometry (GC/MS Model 6890N/5975B Agilent Technology). The chromatograph was equipped with DBWax capillary column. The flow rate of helium (carrier gas) was $1.5 \mathrm{~mL} / \mathrm{min}$. The injection volume was $1 \mu \mathrm{L}$; injector temperature was programmed from 20 to $250^{\circ} \mathrm{C}$ at $180^{\circ} / \mathrm{min}$ then held at $250^{\circ} \mathrm{C}$ for $80 \mathrm{~min}$. The oven temperature was at $60^{\circ} \mathrm{C}$ for $3 \mathrm{~min}$, and from 60 to $220^{\circ} \mathrm{C}$ at $2^{\circ} \mathrm{C} / \mathrm{min}$, from $220^{\circ} \mathrm{C}$ to $245^{\circ} \mathrm{C}$ at $3^{\circ} \mathrm{C} / \mathrm{min}$ then held $20 \mathrm{~min}$ at $245^{\circ} \mathrm{C}$. The flame ionization detector temperature was $250^{\circ} \mathrm{C}$. Mass spectra (MS) were recorded in the electronic impact (EI) and positive chemical ionization (PCI) modes. The transfer line temperature was $250^{\circ} \mathrm{C}$ with source temperature of $250^{\circ} \mathrm{C}$. Mass spectra were scanned at $70 \mathrm{eV}$ (EIMS) and $230 \mathrm{eV}$ (PCIMS) in the range $\mathrm{m} / \mathrm{e} 29-350 \mathrm{amu}$ at $1 \mathrm{~s}$ intervals [18, 19]. Identification of the components was done on the basis of retention index and the comparison of EI mass spectra with reference compounds.

2.3. Effect of Exogenous Application of Pantolactone and Myristic Acid on Bacterial Growth. Pantolactone and myristic acid (Alfa Aesar, USA) were added at 25, 50, and $100 \mu \mathrm{M}$ to King's B medium [20]. Flasks containing $25 \mathrm{~mL}$ of medium were inoculated with $1 \mathrm{~mL}$ of Pseudomonas aeruginosa $\left(10^{8}\right.$ cell $\mathrm{mL}$ ) and incubated on an orbital shaker at $150 \mathrm{rpm} / \mathrm{min}$ at $30^{\circ} \mathrm{C}$. The growth response of bacterial strains was assessed by following the optical density at $540 \mathrm{~nm}$ and was compared by control. Bacterial growth was measured over the period from hours 2 to 72 .

2.4. Effect of Pantolactone and Myristic Acid on Pyocyanin Production by Pseudomonas aeruginosa. Pantolactone and myristic acid were added at 25,50 , and $100 \mu \mathrm{M}$ to King's B medium. Cultures were incubated in an orbital shaking incubator for $9.5 \mathrm{~h}$ at $150 \mathrm{rpm}$ and $30^{\circ} \mathrm{C}$. Pyocyanin was extracted in $1 \mathrm{~mL}$ chloroform, followed by a second extraction into $150 \mu \mathrm{M} 0.2 \mathrm{~N} \mathrm{HCl}$. The culture broth was then centrifuged at $8000 \mathrm{rpm}$ to remove cells. The absorbance of this solution was measured at $520 \mathrm{~nm}$ [21]. Each treatment was conducted with three replicates.

2.5. Effect of Pantolactone and Myristic Acid on Protease, Lipase, and Polygalacturonase Production by Pseudomonas aeruginosa. Pseudomonas aeruginosa isolate E (HQ324110) was grown in $50 \mathrm{~mL}$ of liquid medium in an Erlenmeyer flask $(250 \mathrm{~mL})$ containing $(\mathrm{g} / \mathrm{L}): \mathrm{MgSO}_{4} \cdot 7 \mathrm{H}_{2} \mathrm{O} 0.2, \mathrm{~K}_{2} \mathrm{HPO}_{4} 2.0$, $\mathrm{KH}_{2} \mathrm{PO}_{4}$ 2, and casein $10(\mathrm{pH} 8)$ [22]. The growth medium was supplemented with different concentration of pantolactone and myristic acid $(0,25,50$, and $100 \mu \mathrm{M})$. Assays for proteolytic activity were performed according to OharaNemoto et al. [23]. One unit of enzyme activity was defined as the amount of enzyme that releases $1 \mathrm{mg} \mathrm{mL}^{-1}$ tyrosine per min under the assay conditions. Controls contained autoclaved enzymes instead of active enzymes that were used. For lipase assay, the basal medium consisted of $(\mathrm{g} / \mathrm{L})$ : bacteriological peptone 15.0, yeast extract $5.0, \mathrm{NaCl} 2.0$, $\mathrm{MgSO}_{4} 0.4, \mathrm{~K}_{2} \mathrm{HPO}_{4} 0.3, \mathrm{KH}_{2} \mathrm{PO}_{4} 0.3$, and olive oil $10.0 \mathrm{~mL}$ for lipase induction [24]. The medium was amended with different concentration of pantolactone and myristic acid. Lipase activity was measured by universal titrimetric method [25]. The activity was measured as amount of enzyme required liberating $1 \mu \mathrm{M} \mathrm{mL}^{-1}$ fatty acid per min. The basal medium for pectinase production consisted of $(\mathrm{g} / \mathrm{L})$ : pectin 4, yeast extract 2, $\mathrm{NH}_{4} \mathrm{Cl} 1, \mathrm{MgSO}_{4} 0.5$ [26]. Pantolactone, and myristic acid were added at concentration of $0,25,50$, and $100 \mu \mathrm{M}$ to the growth medium. Cultures were incubated in an orbital shaking incubator for $36 \mathrm{~h}$ at $150 \mathrm{rpm}$ and $37^{\circ} \mathrm{C}$. The culture broth was then centrifuged at $8000 \mathrm{rpm}$ to remove cells. The clear supernatant was collected for enzymes assay. The hydrolytic pectic enzymes were determined according to method of Gomes et al. [26]. A unit of activity is defined as that amount of enzyme which catalyzes the release of $1 \mathrm{mmol}$ of reducing groups per minute and 
TABLE 1: Chemical compounds produced in onion bulbs infected with Pseudomonas aeruginosa. Uninfected onion bulbs were used as control.

\begin{tabular}{|c|c|c|c|c|c|}
\hline \multirow{2}{*}{ Chemical compounds } & \multirow{2}{*}{$\begin{array}{l}\text { Retention } \\
\text { time }\end{array}$} & \multicolumn{2}{|c|}{ Growing onion } & \multicolumn{2}{|c|}{ Dry onion } \\
\hline & & Uninfected & Infected & Uninfected & Infected \\
\hline 4,5-Dihydro-4,5-dimethylfuran-2(3H)-one & 12.69 & - & + & - & + \\
\hline Octanal & 14.205 & - & + & - & + \\
\hline 5, Methyl furfural & 14.692 & - & + & - & + \\
\hline 2-dodecene & 16.301 & - & + & - & + \\
\hline pantolactone & 16.449 & - & + & - & - \\
\hline Undecane & 17.282 & - & + & - & + \\
\hline 2-decenoic acid & 21.640 & - & + & - & + \\
\hline 2-hydroxy, decenoic acid & 24.447 & - & + & - & + \\
\hline $\begin{array}{l}\text { Methyl 2,3,5-tris-O-methyl-4-thio alph. D- } \\
\text { arabinofuranoside }\end{array}$ & 25.7 & - & + & - & + \\
\hline Myristic acid & 27.2 & - & + & - & - \\
\hline (3.alpha.),cholest-5-en-3-ol & 28.5 & - & + & - & + \\
\hline Palmitic acid & 29.8 & - & + & - & + \\
\hline linoleic acid & 33.4 & - & + & - & - \\
\hline 3-dihydro-2(3H)furanone & 33.6 & - & + & - & - \\
\hline 1-Heptadecene & 35.6 & - & + & - & + \\
\hline 1-Octadecene & 35.7 & - & + & - & + \\
\hline Canonical (2-Ethoxydecylphthalimide) & 39.9 & - & + & - & + \\
\hline Octacosane & 40.4 & - & + & - & + \\
\hline
\end{tabular}

expressed as $\mathrm{U} / \mathrm{mL}$. Each treatment was conducted with three replicates.

2.6. Protein Measurement. Cellular protein was determined by the method of Lowry et al. [27] and with bovine serum albumin as the standard.

2.7. Statistical Analysis. Experimental data were subject to a one-way analysis of variance using a computer program (PCstate). Means were compared to test significance between treatments using the LSD at 5\% probability [28].

\section{Results and Discussion}

3.1. Identification of Some Chemical Compounds Produced in an Infected and Uninfected Onion Bulbs. To explore the role of bacterial infection on the induction of chemical compounds in onion tissues, ethyl acetate extracts of artificially infected dry onion and spring onion tissues were analyzed by GC/MS and compared with the uninfected onion tissues at 2 days after infection (Table 1). Based on the extraction method, the compounds obtained in infected growing onion tissues were identified as 4,5-dihydro-4,5-dimethylfuran-2(3H)-one, octanal, 5-methyl furfural, 2-dodecene, pantolactone, undecane, 2-decenoic acid, 2-hydroxy decenoic acid, methyl 2,3,5-tris-O-methyl-4-thio alph, D-arabinofuranoside, myristic acid, (3.alpha.), cholest5-en-3-ol, palmitic acid, linoleic acid, 3-dihydro-2(3H) furanone, 1-heptadecene, 1-octadecene, canonical (2-ethoxydecylphthalimide), and octacosane. However, we found four compounds (i.e., as pantolactone, 4,5-dihydro-4,5-dimethylfuran-2(3H)-one, myristic acid, and linoleic acid) missing in infected storage onion tissues as compared with infected growing onion tissue.

Some of these compounds might be produced by plant or by bacteria. The diffusible signal factor (DSF) was recently identified as unsaturated fatty acids which are produced by a variety of of phytopathogenic bacteria. Wang et al. [29] identified the DSF in Xanthomonas campestris, as cis11 -methyl-2-dodecenoic acid which is an $\alpha, \beta$-unsaturated fatty acid which regulates polysaccharide and extracellular enzyme production both virulence factors. They reported that several other pathogenic bacteria such as $P$. aeruginosa and Mycobacterium sp. also display diffusible signal factor like activity. Yim et al. [30] have argued that the majority of low-molecular-weight organic compounds made and secreted by microbes are likely to function as cell-signalling molecules which modulate the metabolic activities of natural microbial communities.

The discovery that the red alga Delisea produces furanone inhibitors of bacterial quorum sensing stimulated a search for similar activities in plants [31]. This approach is greatly attractive because it does not impose harsh selective pressure for the development of resistance as with antibiotics, because quorum sensing is not directly involved in processes essential for growth of bacteria. The halogenated furanones from D. pulchra provided the first example of quorum sensing compounds produced by a eukaryote $[31,32]$. It was recently demonstrated that several plants, including pea seedlings [33], garlic [34], Medigo sativa [35, 36], vanilla [37], Scorzonera sandrasica [38], and Tremella fuciformis extract [39], are 


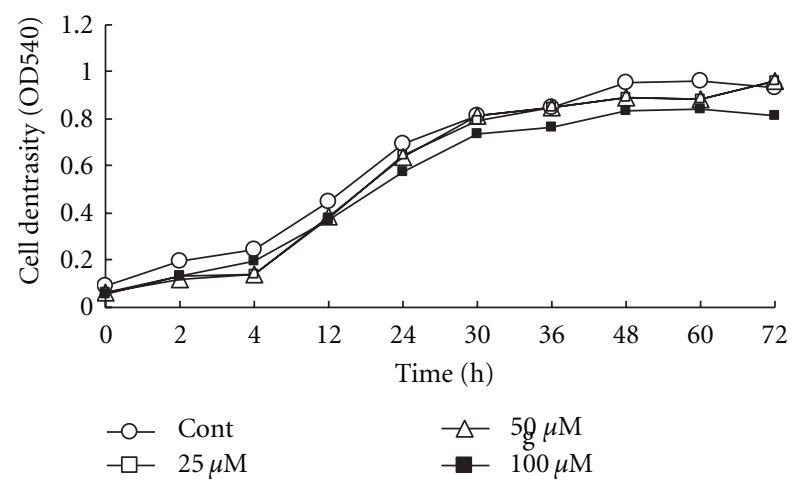

(a)

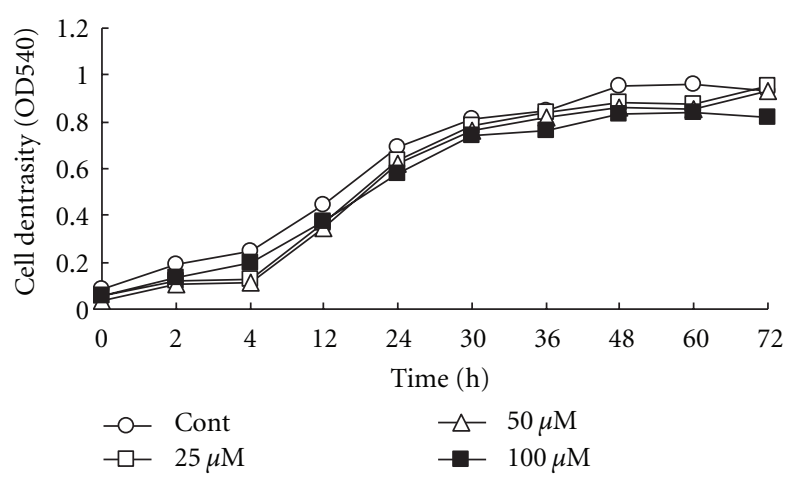

(b)

Figure 1: Effect of pantolactone (a) and myristic acid (b) on the growth rate of Pseudomonas aeruginosa. Values represent the mean of three replicates for each treatment.

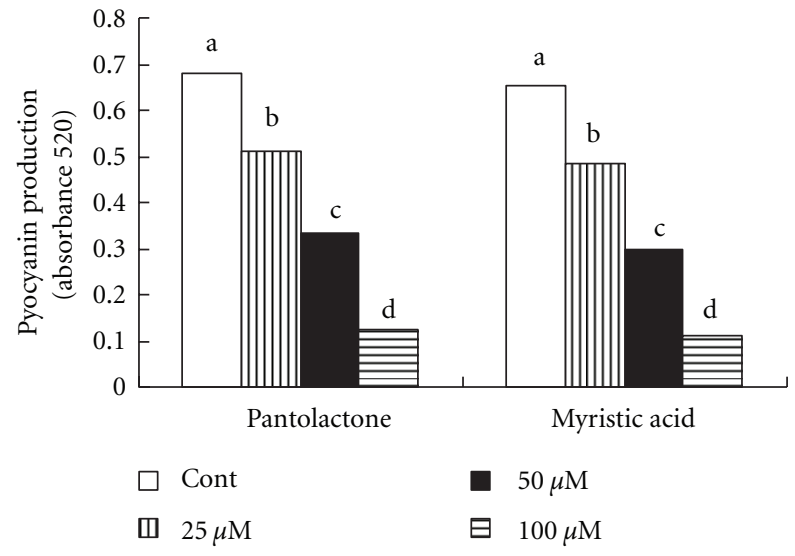

(a)

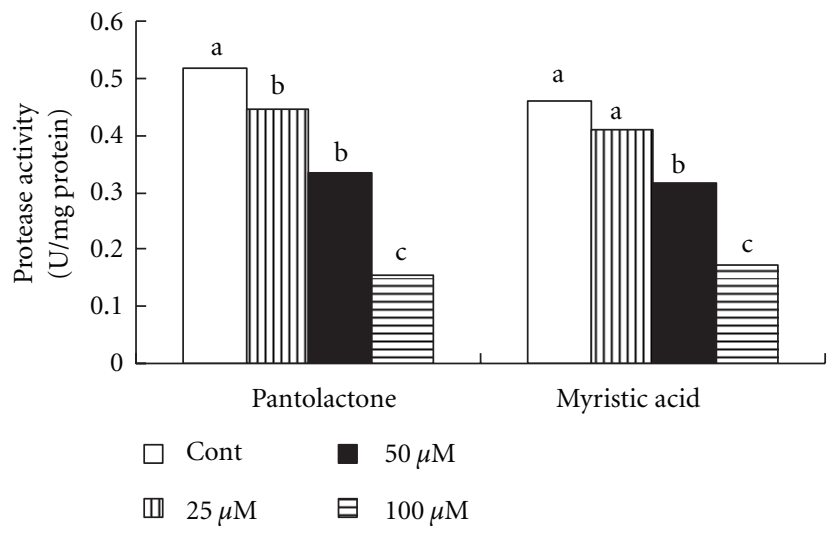

(b)

Figure 2: Effect of pantolactone and myristic acid on pyocyanin production (a) and protease production (b) by Pseudomonas aeruginosa. Values represent mean of three replicates for each treatment. Means with the same letter are not significantly different between treatments within a compound at the $5 \%$ level, using an LSD test.

also able to produce compounds that interfere with bacterial QS [40].

This implies that the quorum sensing signal-mimic compounds are produced by plants to help them deal with the diversity of bacteria that they encounter, just as the furanone mimics of $D$. pulchra help the alga to control the colonization and fouling of its surfaces.

\subsection{Inhibition of Virulence Factor Production by Pantolac-} tone and Myristic Acid. An experiment was designed to investigate the effect of different level of myristic acid and pantolactone on growth and production of extracellular virulence factors. Data presented in Figure 1 show that both tested substances did not have any significant effects on bacterial growth as measured by optical density at $540 \mathrm{~nm}$. To confirm that pantolactone and myristic acid act as quorum sensing inhibitors and effect on virulence factors, we measured the levels of four extracellular virulence factors, namely, pyocyanin, protease, lipase, and polygalacturonase in Pseudomonas aeruginosa culture fluid.
It is obvious that pyocyanin formation by Pseudomonas aeruginosa was reduced about $25 \%$ in the presence of $25 \mu \mathrm{M}$ of pantolactone and about $65 \%$ in the presence of $50 \mu \mathrm{M}$ of pantolactone (Figure 2(a)). Similarly to pantolactone, the addition of $25 \mu \mathrm{M}$ of myristic acid to growth resulted in a $26 \%$ reduction in pyocyanin medium pyocyanin formation (Figure 2(a)). However, $50 \mu \mathrm{M}$ of myristic acid resulted in a $55 \%$ decrease in pyocyanin formation. The production of protease, lipase, and polygalacturonase was significantly inhibited in the presence of myristic acid (Figures 2(b) and 3). Similarly, pantolactone had the same effect except for lipase production (Figures 2(b) and 3).

It is clear that these compounds inhibited some virulence factors (pyocyanin, protease, lipase, and polygalacturonase production) without reduction in bacterial growth. This effect may be providing strong support that these chemical molecules may act as quorum sensing inhibitors rather than an antibacterial effect (quorum-quenching mechanisms are unrelated to static or cidal effects). Data of current research indicate that myristic acid and pantolactone may act 


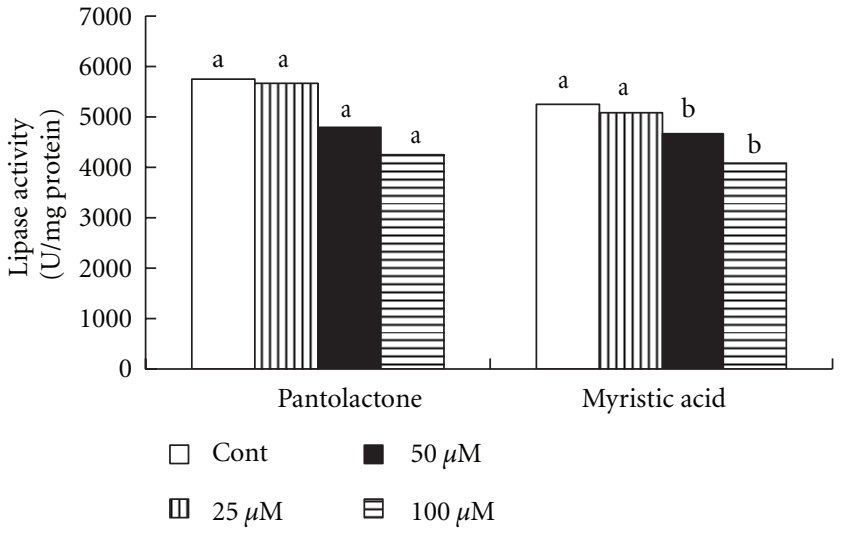

(a)

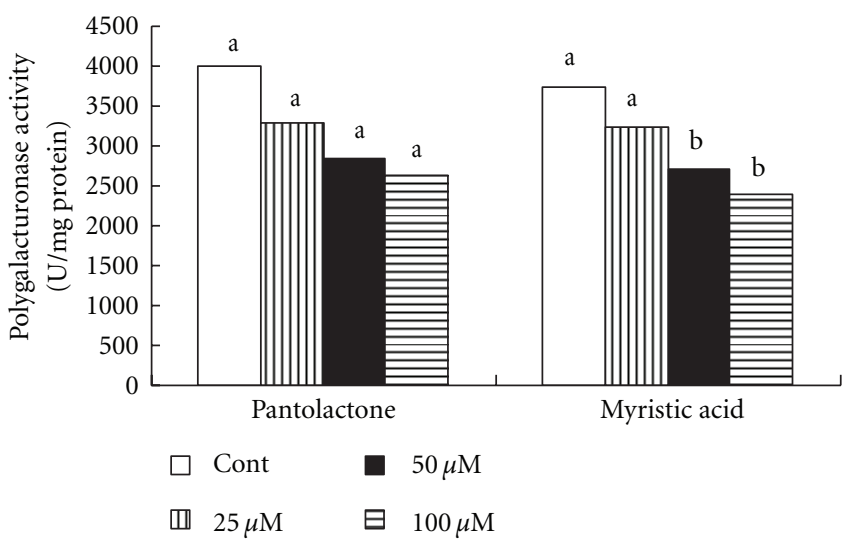

(b)

FIGURE 3: Effect of exogenous application of pantolactone and myristic acid on lipase production (a) and polygalacturonase production (b) by Pseudomonas aeruginosa. Values represent mean of three replicates for each treatment. Means with the same letter are not significantly different between treatments within a compound at the $5 \%$ level, using an LSD test.

as negative signals for regulation of bacterial virulence. Our finding supports the work of Liaw et al. [41] who found that some saturated fatty acids inhibited swarming and virulence factor expression in Proteus mirabilis, Serratia marcescens, and Salmonella enterica. Hentzer et al. [42] demonstrated that the Pseudomonas aeruginosa communication systems can be blocked by halogenated furanone compound. This is a highly specific and effective approach to attenuating bacterial virulence and controlling bacterial infections $[43,44]$. Wu et al. [45] showed that synthetic furanone compound inhibited bacterial quorum sensing and simultaneously reduced the severity of the disease. Defoirdt et al. [46] found that the natural furanone (5Z)-4-bromo-5-(bromomethylene)3-butyl-2(5H)-furanone disrupts quorum-sensing-regulated gene expression in $V$. harvey $i$ by decreasing the DNA-binding activity of the quorum sensing master regulator protein. A group of researchers has collaborated and continuously studied the inhibition of QS using the P. aeruginosa model. They have proved the inhibitory activity of furanone compounds [42], South Florida plant extract [47], and garlic extract [34] in $P$. aeruginosa.

In plant pathology, there is major interest to find natural or synthetic compounds active in small quantities that are capable of interfering with quorum sensing in pathogenic bacteria in order to disrupt their pathogenicity/virulence factor production.

Bacterial diseases are much more difficult to control than fungal diseases because of the lack of effective and benign plant protection products. Using quorum sensing as a target to control and handle detrimental infections caused by human, animal, and plant pathogens is potentially an attractive strategy.

\section{Acknowledgment}

This research was financially supported by Assuit University, Egypt.

\section{References}

[1] S. D. Kominos, C. E. Copeland, B. Grosiak, and B. Postic, "Introduction of Pseudomonas aeruginosa into a hospital via vegetables," Applied Microbiology, vol. 24, no. 4, pp. 567-570, 1972.

[2] M. H. Abd-Alla and S. R. Bashandy, "Bacterial wilt and spot of tomato caused by Xanthomonas vesicatoria and Ralstonia solanacearum in Egypt," World Journal of Microbiology \& Biotechnology, vol. 24, no. 2, pp. 291-292, 2008.

[3] M. H. Abd-Alla, S. R. Bashandy, and S. Schnell, "Occurrence of xanthomonas axonopodis pv. phaseoli, the causal agent of common bacterial blight disease, on seeds of common bean (Phaseolus vulgaris L.) in upper Egypt," Folia Microbiologica, vol. 55, no. 1, pp. 47-52, 2010.

[4] M. H. Abd-Alla, S. R. Bashandy, S. Ratering, and S. Shnell, "First report of soft rot of onion bulbs in storage caused by Pseudomonas aeruginosa in Egypt," Journal of Plant Interaction, vol. 6, no. 4, pp. 229-238, 2011.

[5] M. H. Abd-Alla, S. R. Bashandy, S. Schnell, and S. Ratering, "Isolation and characterization of Serratia rubidaea from dark brown spots of tomato fruits," Phytoparasitica, vol. 39, no. 2, pp. 175-183, 2011.

[6] J. J. Cho, M. N. Schroth, S. D. Kominos, and S. K. Green, "Ornamental plants as carriers of Pseudomonas aeruginosa," Phytopathology, vol. 65, pp. 425-431, 1975.

[7] L. G. Rahme, E. J. Stevens, S. F. Wolfort, J. Shao, R. G. Tompkins, and F. M. Ausubel, "Common virulence factors for bacterial pathogenicity in plants and animals," Science, vol. 268, no. 5219, pp. 1899-1902, 1995.

[8] B. M. Mole, D. A. Baltrus, J. L. Dangl, and S. R. Grant, "Global virulence regulation networks in phytopathogenic bacteria," Trends in Microbiology, vol. 15, no. 8, pp. 363-371, 2007.

[9] R. Karban and I. T. Baldwin, Induced Responses to Herbivory, The University of Chicago Press, Chigaco, Ill, USA, 1997.

[10] R. G. Fray, "Altering plant-microbe interaction through artificially manipulating bacterial quorum sensing," Annals of Botany, vol. 89, no. 3, pp. 245-253, 2002.

[11] S. B. Von Bodman, W. D. Bauer, and D. L. Coplin, "Quorum sensing in plant-pathogenic bacteria," Annual Review of Phytopathology, vol. 41, pp. 455-482, 2003. 
[12] J. K. Holopainen, J. Heijari, A.-M. Nerg, M. Vuorinen, and P. Kainulainen, "Potential for the use of exogenous chemical elicitors in disease and insect pest management of conifer seedling production," The Open Forest Science Journal, vol. 2, pp. 17-24, 2009.

[13] W. D. Bauer and M. Teplitski, "Can plants manipulate bacterial quorum sensing?” Australian Journal of Plant Physiology, vol. 28, no. 9, pp. 913-921, 2001.

[14] S. Kjelleberg and P. Steinberg, "Defenses against bacterial colonization of marine plants," in Phyllosphere Microbiology, S. E. Lindow, E. Poinar, and V. Elliott, Eds., American Phytopathological Society Press, St. Paul, MN, USA, 2002.

[15] R. Daniels, D. E. De Vos, J. Desair et al., "The cin quorum sensing locus of Rhizobium etli CNPAF512 affects growth and symbiotic nitrogen fixation," Journal of Biological Chemistry, vol. 277, no. 1, pp. 462-468, 2002.

[16] M. Teplitski, J. B. Robinson, and W. D. Bauer, "Plants secrete substances that mimic bacterial $\mathrm{N}$-acyl homoserine lactone signal activities and affect population density-dependent behaviors in associated bacteria," Molecular Plant-Microbe Interactions, vol. 13, no. 6, pp. 637-648, 2000.

[17] M. Gao, M. Teplitski, J. B. Robinson, and W. D. Bauer, "Production of substances by Medicago truncatula that affect bacterial quorum sensing," Molecular Plant-Microbe Interactions, vol. 16, no. 9, pp. 827-834, 2003.

[18] S. M. Bureau, A. J. Razungles, and R. L. Baumes, "The aroma of Muscat of Frontignan grapes: effect of the light environment of vine or bunch on volatiles and glycoconjugates," Journal of the Science of Food and Agriculture, vol. 80, no. 14, pp. 20122020, 2000.

[19] R. Schneider, R. Baumes, C. Bayonove, and A. Razungles, "Volatile compounds involved in the aroma of sweet fortified wines (vins doux naturels) from Grenache noir," Journal of Agricultural and Food Chemistry, vol. 46, no. 8, pp. 3230-3237, 1998.

[20] E. O. King, M. K. Ward, and D. E. Raney, "Two simple media for the demonstration of pyocyanin and fluorescin," The Journal of Laboratory and Clinical Medicine, vol. 44, no. 2, pp. 301307, 1954.

[21] D. W. Essar, L. Eberly, A. Hadero, and I. P. Crawford, "Identification and characterization of genes for a second anthranilate synthase in Pseudomonas aeruginosa: interchangeability of the two anthranilate synthase and evolutionary implications," Journal of Bacteriology, vol. 172, no. 2, pp. 884-900, 1990.

[22] R. Chakraborty and M. Srinivasan, "Production of a thermostable alkaline protease by a new Pseudomonas sp. by solid substrate fermentation," Journal of Microbiology and Biotechnology, vol. 8, pp. 7-16, 1993.

[23] Y. Ohara-Nemoto, M. Sasaki, M. Kaneko, T. Nemoto, and M. Ota, "Cysteine protease activity of streptococcal exotoxin B," Canadian Journal of Microbiology, vol. 40, no. 11, pp. 930-936, 1994.

[24] S. N. Baharum, A. B. Salleh, C. N. A. Razak, M. Basri, M. B. A. Rahman, and R. N. Z. R. A. Rahman, "Organic solvent tolerant lipase by Pseudomonas sp. strain S5: stability of enzyme in organic solvent and physical factors affecting its production," Annals of Microbiology, vol. 53, no. 1, pp. 75-83, 2003.

[25] S. Fadiloğlu and Z. Söylemez, "Kinetics of lipase-catalyzed hydrolysis of olive oil," Food Research International, vol. 30, no. 3-4, pp. 171-175, 1997.

[26] I. Gomes, R. K. Saha, G. Mohiuddin, and M. M. Hoq, "Isolation and characterization of a cellulase-free pectinolytic and hemicellulolytic thermophilic fungus," World Journal of Microbiology \& Biotechnology, vol. 8, no. 6, pp. 589-592, 1992.
[27] O. H. Lowry, N. J. Rosebrough, A. L. Farr, and R. J. Randall, "Protein measurement with the Folin phenol reagent," The Journal of Biological Chemistry, vol. 193, no. 1, pp. 265-275, 1951.

[28] M. Rao, U. Blane, and M. Zonnenberg, PC-State Version I A, The University of Georgia, 1985.

[29] L. H. Wang, Y. He, Y. Gao et al., "A bacterial cell-cell communication signal with cross-kingdom structural analogues," Molecular Microbiology, vol. 51, no. 3, pp. 903-912, 2004.

[30] G. Yim, H. Huimi Wang, and J. Davies, "The truth about antibiotics," International Journal of Medical Microbiology, vol. 296, no. 2-3, pp. 163-170, 2006.

[31] M. Givskov, R. De Nys, M. Manefield et al., "Eukaryotic interference with homoserine lactone-mediated prokaryotic signalling," Journal of Bacteriology, vol. 178, no. 22, pp. 66186622, 1996.

[32] M. Manefield, R. de Nys, N. Kumar et al., "Evidence that halogenated furanones from Delisea pulchra inhibit acylated homoserine lactone (AHL)-mediated gene expression by displacing the AHL signal from its receptor protein," Microbiology, vol. 145, no. 2, pp. 283-291, 1999.

[33] L. Delalande, D. Faure, A. Raffoux et al., "N-hexanoyl-Lhomoserine lactone, a mediator of bacterial quorum-sensing regulation, exhibits plant-dependent stability and may be inactivated by germinating Lotus corniculatus seedlings," FEMS Microbiology Ecology, vol. 52, no. 1, pp. 13-20, 2005.

[34] T. B. Rasmussen, T. Bjarnsholt, M. E. Skindersoe et al., "Screening for quorum-sensing inhibitors (QSI) by use of a novel genetic system, the QSI selector," Journal of Bacteriology, vol. 187, no. 5, pp. 1799-1814, 2005.

[35] N. D. Keshavan, P. K. Chowdhary, D. C. Haines, and J. E. González, "L-canavanine made by Medicago sativa interferes with quorum sensing in Sinorhizobium meliloti," Journal of Bacteriology, vol. 187, no. 24, pp. 8427-8436, 2005.

[36] W. D. Bauer, U. Mathesius, and M. Teplitski, "Eukaryotes deal with bacterial quorum sensing," ASM News, vol. 71, no. 3, pp. 129-135, 2005.

[37] J. H. Choo, Y. Rukayadi, and J. K. Hwang, "Inhibition of bacterial quorum sensing by vanilla extract," Letters in Applied Microbiology, vol. 42, no. 6, pp. 637-641, 2006.

[38] G. Bosgelmez-Tinaz, S. Ulusoy, A. Ugur, and O. Ceylan, "Inhibition of quorum sensing-regulated behaviors by Scorzonera sandrasica," Current Microbiology, vol. 55, no. 2, pp. 114-118, 2007.

[39] H. Zhu and S. J. Sun, "Inhibition of bacterial quorum sensingregulated behaviors by Tremella fuciformis extract," Current Microbiology, vol. 57, no. 5, pp. 418-422, 2008.

[40] W. D. Bauer and J. B. Robinson, "Disruption of bacterial quorum sensing by other organisms," Current Opinion in Biotechnology, vol. 13, no. 3, pp. 234-237, 2002.

[41] S. J. Liaw, H. C. Lai, and W. B. Wang, "Modulation of swarming and virulence by fatty acids through the RsbA protein in Proteus mirabilis," Infection \& Immunity, vol. 72, no. 12, pp. 6836-6845, 2004.

[42] M. Hentzer, H. Wu, J. B. Andersen et al., "Attenuation of Pseudomonas aeruginosa virulence by quorum sensing inhibitors," The EMBO Journal, vol. 22, no. 15, pp. 3803-3815, 2003.

[43] U. Müh, M. Schuster, R. Heim, A. Singh, E. R. Olson, and E. P. Greenberg, "Novel Pseudomonas aeruginosa quorum-sensing inhibitors identified in an ultra-high-throughput screen," Antimicrobial Agents \& Chemotherapy, vol. 50, no. 11, pp. 3674-3679, 2006.

[44] D. Ren, M. Givskov, T. B. Rasmussen, and N. Balaban, "Quorum-sensing inhibitory compounds," in Control of 
Biofilm Infections by Signal Manipulation, N. Balaban, Ed., Springer Series on Biofilms, pp. 51-77, Springer, 2008.

[45] H. Wu, Z. Song, M. Hentzer et al., "Synthetic furanones inhibit quorum-sensing and enhance bacterial clearance in Pseudomonas aeruginosa lung infection in mice," Journal of Antimicrobial Chemotherapy, vol. 53, no. 6, pp. 1054-1061, 2004.

[46] T. Defoirdt, C. M. Miyamoto, T. K. Wood et al., "The natural furanone (5Z)-4-bromo-5-(bromomethylene)-3-butyl$2(5 \mathrm{H})$-furanone disrupts quorum sensing-regulated gene expression in Vibrio harveyi by decreasing the DNA-binding activity of the transcriptional regulator protein luxR," Environmental Microbiology, vol. 9, no. 10, pp. 2486-2495, 2007.

[47] A. Adonizio, K. F. Kong, and K. Mathee, "Inhibition of quorum sensing-controlled virulence factor production in Pseudomonas aeruginosa by south Florida plant extracts," Antimicrobial Agents \& Chemotherapy, vol. 52, no. 1, pp. 198203, 2008 . 

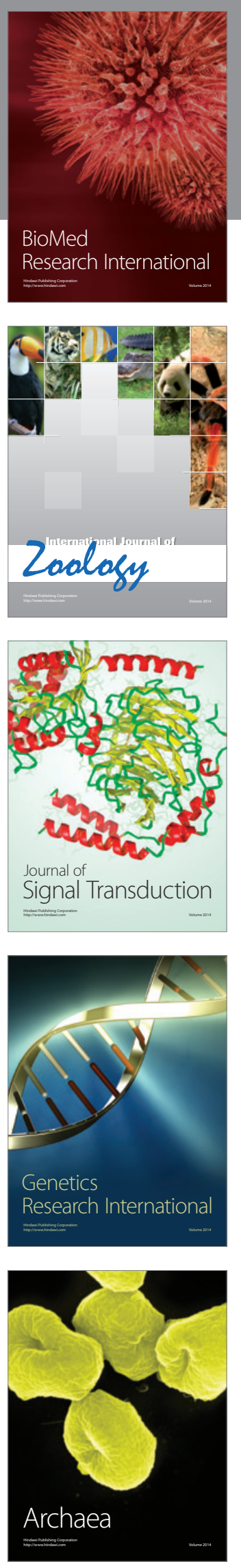
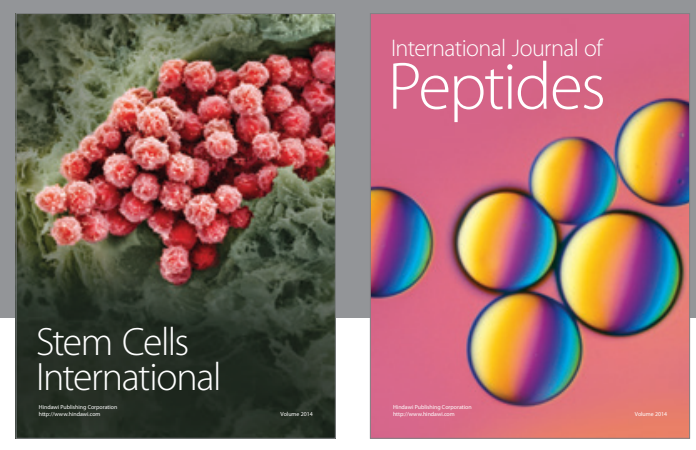

Submit your manuscripts at

http://www.hindawi.com
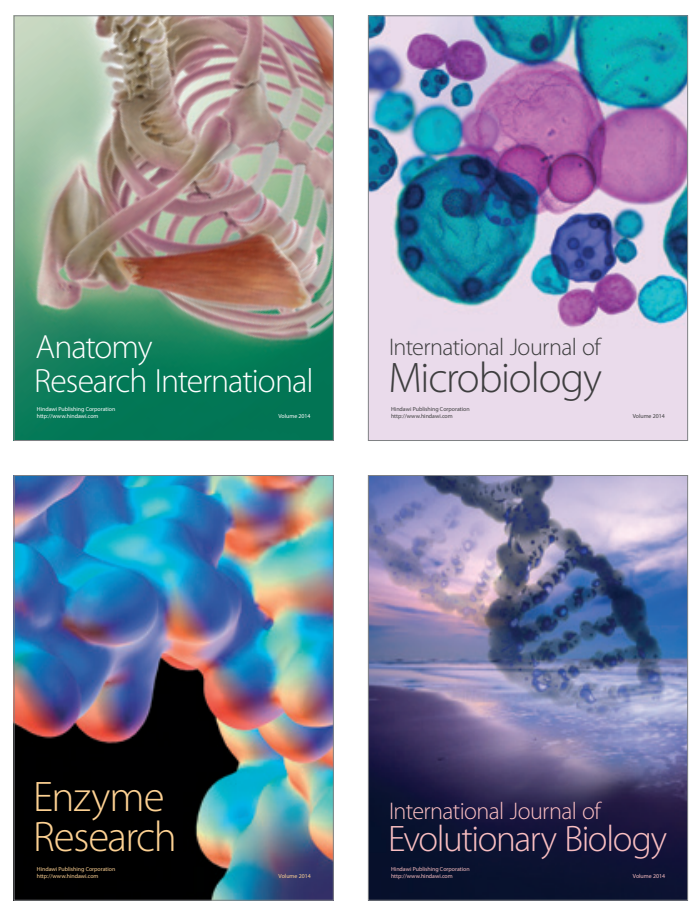
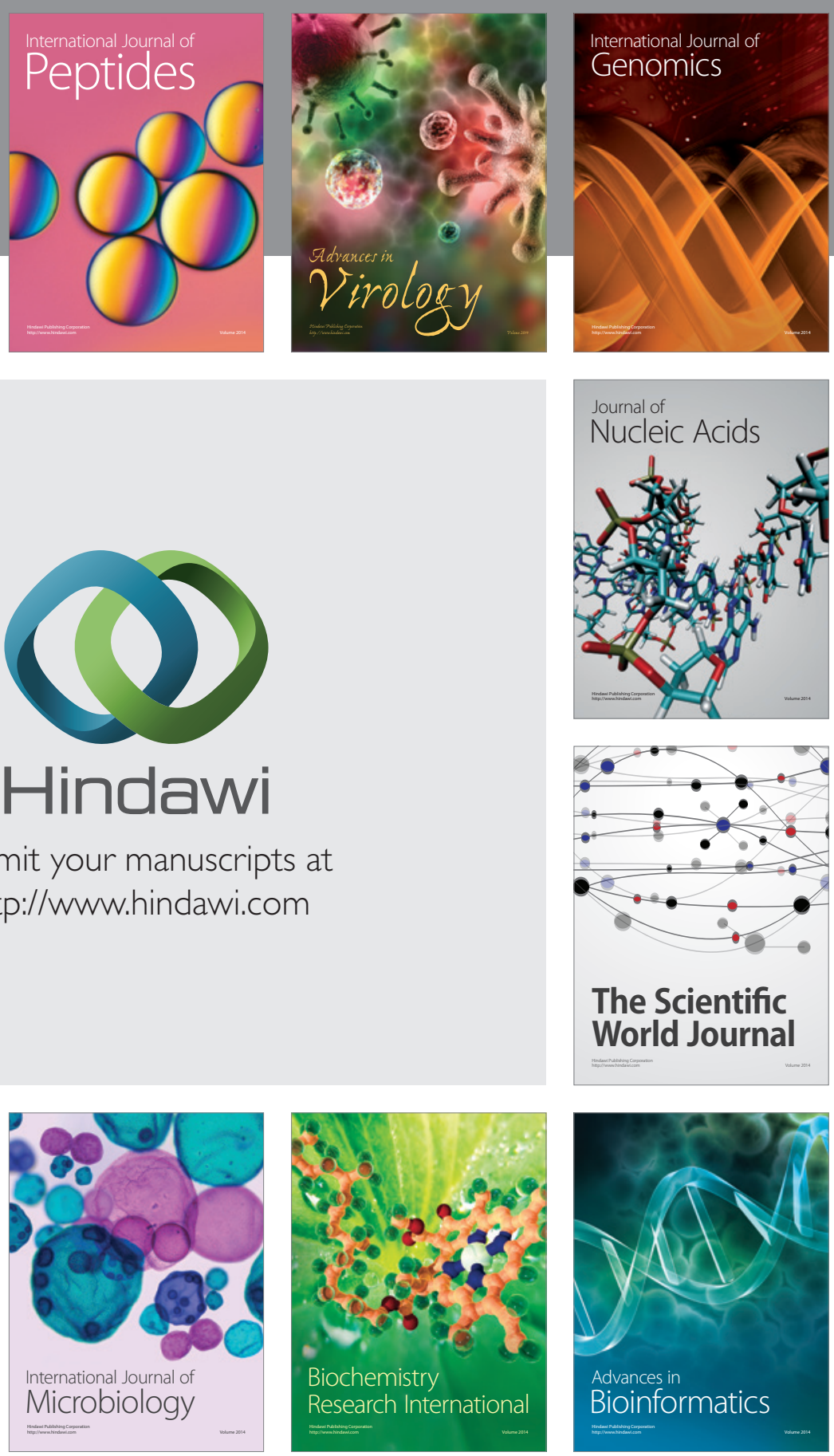

The Scientific World Journal
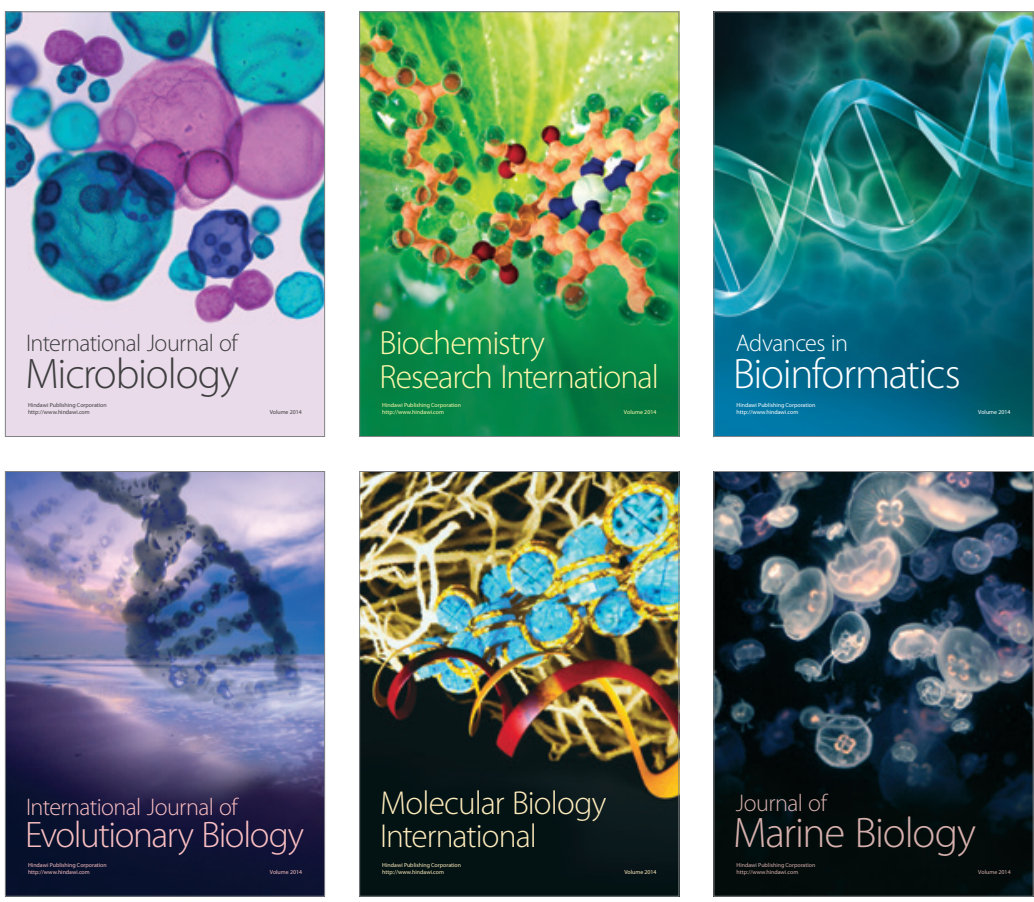